\title{
ÇİLEK AROMASININ DEPOLAMA KARARLILIĞI ÜZERİNE PÜSKÜRTEREK KURUTMA YÖNTEMIYYLE ENKAPSÜLASYON İŞLEMİNİN ETKİSİ VE MİKROKAPSÜLLERİN MODEL GIDALARDA ETKİNLİĞİNIN BELİRLENMESİ
}

\author{
Ferhan Balc1-Torun*, Feramuz Özdemir \\ Akdeniz Üniversitesi, Mühendislik Fakültesi, Gıda Mühendisliği Bölümü, , Antalya, Türkiye
}

Geliş / Received: 14.03.2021; Kabul / Accepted: 05.05.2021; Online bask1 / Published online: 10.05.2021

Balc1-Torun, F., Özdemir, F. (2021). Çilek aromasının depolama kararlılığı üzerine püskürterek kurutma yöntemiyle enkapsülasyon işleminin etkisi ve mikrokapsüllerin model gıdalarda etkinliğinin belirlenmesi. GIDA (2021) 46 (3) 751-765 doi: 10.15237/gida. GD21070

Balct-Torun, F., Özdemir, F. (2021). Influence of the spray-drying encapsulation on the storage stability of strawberry aroma and efficience of microcappsules in model foods. GIDA (2021) 46 (3) $751-765$ doi: 10.15237/gida. GD21070

ÖZ

Çalışmada sıvı çilek aroması püskürterek kurutma yöntemiyle enkapsüle edilmiş ve elde edilen mikrokapsüllerin depolama stabilitesi ve model gıdalarda kullanım etkinliği belirlenmiştir. $\mathrm{Bu}$ amaçla mikrokapsüller farklı sıcaklıklarda (4 ve $\left.25^{\circ} \mathrm{C}\right) 60$ gün süre ile depolanmış ve aroma salınımı, nem miktarı, su aktivitesi, kitle yoğunluğu ve parçacık boyutu dağılımı analizleri yapılmıştır. Ayrıca ticari sıvı ve enkapsüle çilek aromaları kullanılarak üretilen çikolata ve keklerde duyusal analizler gerçekleştirilmiştir. Çalışma sonuçları enkapsülasyon işleminin aroma salınımını yaklaşık \%50 oranında azalttığını, düşük sıcaklıklardaki depolamanın aroma korunumunu daha iyi sağladığını göstermiştir.z mikrokapsüllerin nem miktarı, su aktivitesi ve parçacık boyutu değerleri depolama süresi ile birlikte artış gösterirken, kitle yoğunluğu değerinin azaldığı tespit edilmiştir. Duyusal analiz sonucunda enkapsüle çilek aromaları ile üretilen çikolata ve keklerin koku, tat, aroma ve genel beğeni açısından sıvı formda aroma kullanılarak üretilen ürünlere göre daha çok beğenildiği belirlenmiştir. Sonuçlar enkapsülasyon işleminin depolama stabilitesini arttırmasının yanında katkılandığ1 gıdaların işlenmesi sırasındaki kararlılıklarını da geliştirdiğini göstermiştir.

Anahtar kelimeler: Aroma, çilek, enkapsülasyon, püskürterek kurutma, depolama, model gida

\section{INFLUENCE OF THE SPRAY-DRYING ENCAPSULATION ON THE STORAGE STABILITY OF STRAWBERRY AROMA AND EFFICIENCE OF MICROCAPPSULES IN MODEL FOODS}

\begin{abstract}
In this study, it was aimed to investigate the storage stability and usage into model foods of strawberry aroma microcapsules obtained by spray-drying method. Accordingly, microcapsules were stored at different temperatures $\left(4\right.$ and $25^{\circ} \mathrm{C}$ ) for 60 days and aroma release, moisture content, water activity, bulk density and particle size distribution analyses were performed. Sensory analysis was performed on chocolate and cakes produced with liquid form and encapsulated strawberry flavors. While the moisture content, water activity and particle size values of the powder microcapsules increased by
\end{abstract}

\footnotetext{
* Yazışmalardan sorumlu yazar / Corresponding author;

$\checkmark$ ferhan85@hotmail.com,

(c) $(+90) 2423106520$

冝(+90) 2423106306
}

Ferhan BalcI-Torun; ORCID no: 0000-0002-8972-1087

Feramuz Özdemir; ORCID no: 0000-0001-6618-2896 
the storage time, bulk density value decreased. As a result of the sensory analysis, it was determined that chocolate and cakes produced with encapsulated strawberry flavors were more appreciated than the products produced using aroma in liquid form. These results indicated that the encapsulation process not only increases the storage stability in terms of flavor, but also improves the stability during processing of the foods.

Keywords: Aroma, strawberry, encapsulation, spray drying, storage, model food

\section{GİRİ̧}

İnsanoğlunun gidaların tat, lezzet ve aromasını korumak ve geliştirmek için yüzyıllardır sürdürdüğü çabası günümüzde de artarak devam etmektedir. Bu amaçla özellikle gıdaların işlenmesi ve depolanması sürecinde azalan, değişen veya oluşan tat ve aromanın gidaya kazandirılması amaciyla gida katkisı olarak aroma maddeleri kullanılmaktadır (Torun ve Özdemir, 2011). Aroma bileşenleri oda sıcaklı̆̆ında uçucu fazında olan ve burun boşluğundaki koku reseptörleri ile etkileşime giren uçucu moleküller olarak tanımlanmaktadır (Zuidam ve Heinrich, 2010). Birçok uçucu organik molekülden oluşan aroma maddeleri 50-600 Da aralı̆̆ında değişen düşük molekül ağırlığına sahip olup, alkoller, karboniller, asitler, esterler, laktonlar ve fenoller gibi bileşenlerin farklı reaksiyonları sonucu meydana gelmektedir (Atak, 2018). Amino asitlerden oluşan aldehit ve ketonlar ile bunların dönüşümü esnasinda meydana gelen alkoller aroma oluşumunda önemli rol oynamaktadır. Aroma maddelerinden bir diğer önemli grubu olan esterler ise genellikle meyvelerin karakteristik aroma tanımlamasından sorumludur. Örneğin etil esterleri "etil asetat" bileşeninden başlayıp uzun zincirlerle "etil lorat" bileșenine kadar devam eden meyve aromasindan ve aromanin yoğunluğundan sorumlu bileşenlerdir (Rowe, 2005; Gonçalves vd., 2018).

Geçmişte bitkisel kaynaklardan özütlenerek kullanilan aroma maddeleri, yapilarının belirlenmesiyle birlikte kimyasal olarak sentezlenmeye başlanmıştır. Günümüzde kullanılan aroma katkılarının \%80'inden fazlas1 sentetik olarak elde edilmektedir (Longo ve Sanroman, 2006). Tüketime sunulan işlenmiş gıdalar incelendiğinde, bunların birçoğunda çilek, muz, karpuz, vanilya, nane, limon, findik, kahve ve kakao gibi aroma maddelerinin kullanıldığ 1 görülmektedir. Bunlar arasında çilek aromasının yaygın olarak kullanıldığı dikkat çekmektedir.
Çilek aromasinda 300'den fazla aroma bileşeninin bulunduğu ve ana bileşenlerinin esterler, asitler, aldehitler, alkoller ve terpenlerden meydana geldiği görülmüştür (Zabetakis ve Holden, 1997). Aromaya katkıda bulunan diğer gruplar arasında kükürt bileşikleri, asetaller, furanlar, fenoller, epoksitler ve hidrokarbonlar bulunmaktadır. Bunlar arasinda metil, etil ester, furanonlar, C6bileşiği aldehitleri ve C6-türevi bileşikleri, çilek aromasindan sorumlu aroma maddeleri olarak kabul edilmektedir (Schieberle ve Hofmann, 1997; Zabetakis ve Holden, 1997; Zabetakis vd., 1999; Pelayo vd., 2003).

Aroma maddeleri fiziksel özelliklerine göre çeşitlilik göstermekle birlikte genellikle katı, sıvı veya macunumsu formda olup fiziksel formu genellikle katkılanacak ürüne uygunluğu veya kullanım amacına göre değişmektedir. Sıvı formdaki bir ürüne katı formda bulunan bir aroma, kuru toz bir ürün karışımında da sıvı aroma maddesinin kullanımında teknolojik sıkıntılar yaşanabilmektedir. Gıda katkı maddeleri arasında fiyatları oransal olarak yüksek olan aroma maddelerinin depolama stabilitelerini arttırmak, işlenmeleri ve tüketimleri sırasındaki salınımlarının kontrolünü sağlamak oldukça önemlidir. Son yıllarda, gıda endüstrisinde oksijen, nem, sıcaklık, ışık ve benzeri çevre koşullarına karşı koruma sağlayan ve aktif bileşenin doğru yerde, doğru zamanda kontrollü salınımına olanak veren enkapsülasyon uygulamaları gittikçe yaygınlaşmaktadır. Özellikle gida etken bileşenlerinin, renk maddelerinin, enzimlerin, vitaminlerin, minerallerin, aroma gibi katk1 maddelerinin ve yararlı mikroorganizmaların enkapsülasyonuna yönelik çalışmaların yapıldığı görülmektedir (Gibbs vd., 1999; Zuidam ve Heinrich, 2010; Zhu vd., 2012). Hassas bir maddenin veya karışımın, koruyucu bir kabuk veya duvar oluşturabilen başka bir maddenin veya karışımın içerisine hapsedilmesi veya tutulması olarak tanımlanan enkapsülasyon işlemi 
püskürterek kurutma, püskürterek soğutma, dondurarak kurutma, ekstrüzyon kaplama, akışkan yatakta kaplama, lipozoma hapsetme ve koaservasyon gibi farkl tekniklerle yapilabilmektedir (Madene vd., 2006). Gida endüstrisinde aroma maddelerinin enkapsülasyonunda kullanılan teknikler içinde en yayg1n olanı püskürterek kurutma yöntemidir. Sürekli üretim olanağı, ekipman kullanımının kolaylığı, düşük maliyet, geniş taşıyıcı madde seçimi, uçucu bileşenlerin iyi tutulması ve son ürün stabilitesi bu yöntemin en çok tercih edilme nedenleridir (Re, 1998; Jimenez vd., 2004; Rodriguez-Huezo vd., 2004). Püskürterek kurutmada kapsüllenecek olan aroma damlacıklarının, küresel partiküllerin katı çeperleri içinde hapsedilmesi amaçlanmaktadır. Bu işlem, kaplama materyali belli bir konsantrasyonun üzerinde iken, uçucu bileşiklerin partikül yüzeyine kadar yeterince hareket edemeyeceği ve atmosfere salınamayacağ1 teorisi üzerine kurulmuştur. $\mathrm{Bu}$ nedenle püskürterek kurutma esnasinda su ortamdan uzaklaşırken, taşıyıcı madde yüzeyde konsantre olmakta ve yüzeyde ileri derecede aroma kaybını önlemek üzere etkili bir sızdırmazlık oluşturmaktadır (Bhandari ve Howes, 1999; Zeller vd., 1999; Kargel, 2000). Püskürterek kurutma ile elde edilen mikrokapsüllerin boyutu 0.2- $5000 \mu \mathrm{m}$ arasinda değişmekte olup, kullanılan kapsülleme materyaline ve hazırlanma prosedürüne bağlı olarak mikrokapsüller çok farklı şekilde oluşabilmektedir (Krishnan vd., 2005). Mikrokapsülasyon işleminde kullanılacak olan kaplama materyali seçimi işlemin başarısını etkileyen önemli bir unsur olmakla birlikte; kaplama materyali çekirdek materyalini dış etkilere karşı bariyer görevi görerek korumak ve herhangi başka bir bileşenle reaksiyona girmesini engellemekle görevlidir. Bununla birlikte kaplama istenilen çözgende çözünebilmeli ve çekirdek materyalini çok iyi kaplayarak hem ürünün işlenmesi hem de depolanması sırasında koruyabilme özelliğine sahip olmalıdır. Aynı zamanda istenilen koşullarda çekirdek materyalinin salınımını kolaylaştırırken, düşük maliyetli, tatsız ve temini kolay olmalıdır. Ancak bütün bu özelliklerin tek bir materyal ile sağlanmas1 oldukça güç olduğu için enkapsülasyon işleminde farklı kaplama materyallerinin bir arada kullanilması önerilmektedir (Koç vd., 2010). Maltodekstrin ve modifiye nişasta gibi karbonhidratlar taşıyıcı madde veya duvar materyali olarak siklikla kullanılan, ucuz, yüksek konsantrasyonlarda düşük viskozite gösteren, yüksek çözünürlüğe sahip, oksidasyona duyarlı maddelerdir. Halkalı yapıdaki oligosakkaritler olan siklodekstrinler, gıda endüstrisinde pek çok kullanım alanı bulunmakla birlikte, özellikle aroma ve renk maddelerinin, vitaminlerin ve doymamış yağların kapsüllenmesi, ayrıca gıdaların duyusal ve besleyici özelliklerinin arttırılması için kullanılmaktadır. Bitki salgisı olan arabik gam suda son derece iyi çözünebilmesi $(\geq \% 50)$ nedeniyle diğer doğal gam maddelerinden ayrılmaktadır. Arabik gam gidalarda özellikle aroma koruyucu, köpük stabilizatörü, bağlayıc1, emülgatör ve stabilizatör olarak kullanılmaktadır (Burdock, 1998). Modifiye nişastalar, yapisına lipofilik süksinik asit eklenerek emülsifiye edici özellik kazandırılmış hidrolize nişastalardır. Modifiye nişastalar, yapışkanlık, bağlama, kaplama, toparlama, emülsiyon stabilizasyonu, jelleşme, şeffaflık, nem tutma, stabilizasyon ve kıvam artırıcılık gibi özelliklerinden dolayı gıdalarda s1klıkla tercih edilmektedir (Karaoğlu ve Kotancilar, 1998).

Literatürde çilek aromasının püskürterek kurutma yöntemiyle enkapsülasyonunu konu alan az sayıda çalışma (Pellicer vd., 2018; Balc1-Torun ve Özdemir, 2021) mevcut olup, püskürterek kurutulmuş toz aroma mikrokapsüllerinin depolama stabilitesinin incelendiği bir çalışmaya ise rastlanılamamıştır. Nitekim bu makalede tarafımızdan yapılan çalışma sonucunda (Balc1Torun ve Özdemir, 2021) belirlenen optimum şartlarda üretilen toz çilek mikrokapsüllerinin depolama stabilitesinin ve bazı model gidalardaki kullanımının araştırılması amaçlanmıştır. Bu amaçla \%16.12 modifiye nişasta, \%9.76 arabik gam, \%4.12 çözünür lif, \%1 $\beta$-siklodekstrin taşıyıcı madde karışımı kullanılarak, $190{ }^{\circ} \mathrm{C}$ giriş sicaklığında kurutularak üretilen toz çilek mikrokapsülleri farklı 2 sicaklıkta $\left(4\right.$ ve $\left.25^{\circ} \mathrm{C}\right) 60$ gün süreyle depolanmış ve depolama periyodunda örneklerin aroma salınımları ile su aktivitesi, nem 
değeri, kitle yoğunluğu ve parçacık boyutundaki değişimler incelenmiştir. Ayrıca üretilen mikrokapsüllerle çikolata ve kek üretimleri yapılarak ürünlerin beğeni durumları da belirlenmiştir.

\section{MATERYAL VE YÖNTEM \\ Materyal}

Çalışma kapsamında kullanılan doğal sıvı aroma maddesi Aromsa Besin Aroma ve Katk1 Maddeleri Sanayi Ticaret A.Ş. (Gebze, Kocaeli) firmasından temin edilmiştir. Enkapsülasyon ișleminde kullanılan taşıyıcı materyaller olan maltodekstin ve Nutriose çözünür lif, Cleargum modifiye nişasta "Roquette Frères" (Lestrem, Fransa) firmasindan, model gida üretiminde kullanılan çikolata ise Callebaut (Belçika) firmasından temin edilmiştir. Analizlerde kullanılan diğer kimyasallar analitik saflıkta SigmaAldrich' den (Darmstadt, Almanya) temin edilmiştir.

\section{Enkapsülasyon işlemi}

Çilek aromasının enkapsülasyon işlemi Balc1Torun ve Özdemir (2021)'in belirttiği optimum şartlara göre mini püskürtmeli kurutucuda (Büchi Mini Spray Dryer B-290, Flawil, İsviçre) gerçekleştirilmiştir. Kurutma işleminde taşıyıcı madde karışımı \%31 (ağırlık/hacim) olarak hazırlanmış, bu karışıma kuru maddenin \%10' u kadar çilek aroması ilave edilmiştir. Taşıyıcı madde karışımını ise \%16.12 modifiye nişasta, $\% 9.76$ arabik gam, $\% 4.12$ çözünür lif ve $\% 1 \beta$ siklodekstrin oluşturmuş olup su içerisinde çözündürülmüştür. Kurutma öncesinde karışım $17000 \mathrm{~d} / \mathrm{dk}$ hızda 5 dakika süreyle homojenizatör yardımı ile (Ultraturrax T25 Basic Staufen, Almanya) homojenize edilmiştir. Elde edilen karışım hava giriş sıcaklığı $190{ }^{\circ} \mathrm{C}$, ürün çıkış sıcaklığ1 $75-80{ }^{\circ} \mathrm{C}$, besleme hızı $5-8 \mathrm{~mL} / \mathrm{dk}$ ve aspirasyon hızı $30 \mathrm{~m}^{3} / \mathrm{sn}$ koşullarında püskürtmeli kurutucuyla toz ürüne dönüştürülmüştür.

\section{Aroma mikrokapsüllerinin depolanması}

Çilek aroması mikrokapsülleri ve enkapsülasyon işlemi uygulanmamış sıvı formdaki aromalar (kontrol örnekleri) amber renkli cam kavanozlara, her bir kavanoza $15^{\prime}$ er gram olacak şekilde koyularak örnekler 4 ve $25{ }^{\circ} \mathrm{C}$ sicaklikta 2 ay süre depolanmıştır. Depolamanın 0., 15., 30. ve 60. günlerinde alınan örneklerde nem miktarı, su aktivitesi, aroma profili, partikül boyutu ve yığın yoğunluğu analizleri, sıvi örnekte ise aroma analizi yapılmıştır.

\section{SPME/GC-MS ile aroma analiz koşulları}

Siv1 ve toz formdaki örneklerin aroma analizleri Balcı-Torun ve Özdemir (2021) tarafindan belirtilen analiz şartları kullanılarak, GC-MS (QP2010-Ultra, Shimadzu, Kyoto, Japonya) cihazı ile yapılmış, analiz sırasında cihazın Katı Faz Mikroekstraksiyon tekniği (SPME) kullanılarak ekstraksiyon ünitesi (AOC-5000Auto Sampler, Shimadzu, Kyoto, Japonya) kullanılmıștır. Aroma analiz sonuçları \% alan cinsinden hesaplanmış olup, uçucu bileşenlerinin tanımlanmas $\mathrm{C}_{7}-\mathrm{C}_{24}$ alkan standardının metotta yürütülmesi ile elde edilen tutunma indeksi (Kovats'Index) sonuçları ile cihaz yazılımı (GCMS solution 5.60) kullanılarak gerçekleştirilmiştir. Ayrıca yazılım tarafindan tanımlanan bileşenlerin kontrolünde bilimsel makaleler ile Wiley 10 ve NIST 02 kütüphanelerindeki alıkonma indekslerinden de yararlanılmıştır.

Örneklerin aroma profil analizi $100 \mu \mathrm{m}$ PDMS fiber ile SPME metoduna göre yapılmıştur. SPME metodunda işlem sicaklı̆g $40{ }^{\circ} \mathrm{C}$, ekstraksiyon süresi 15 dakika, karıştırma hızı 250 d/dk (5 s açık, 2 s kapali), desorpsiyon süresi ise 10 dakika olarak ayarlanmıştır. GC-MS analizinde TRB5-MS (30 $\mathrm{m} \times 0.25 \mathrm{~mm} \times 0.25 \mu \mathrm{m}$ ) kolon kullanılmış olup firın sicaklık program $40^{\circ} \mathrm{C}$ 'de $5 \mathrm{dk}$ bekleme, 4 ${ }^{\circ} \mathrm{C} / \mathrm{dk}$ artışla $100^{\circ} \mathrm{C}$ ' ye yükselme ve bu sıcaklikta $3 \mathrm{dk}$ bekleme, $10{ }^{\circ} \mathrm{C} / \mathrm{dk}$ artışla $200{ }^{\circ} \mathrm{C}$ ' ye yükselme ve bu sicaklikta $3 \mathrm{dk}$ bekleme olarak belirlenmiştir. GC-MS' te dedektör sıcaklığı 275 ${ }^{\circ} \mathrm{C}$, taşıyıcı gaz helyum $(1.78 \mathrm{~mL} / \mathrm{dk})$, enjeksiyon ve iyon kaynağı sıcaklığ1 $200{ }^{\circ} \mathrm{C}$, kütle aralığı 30$500 \mathrm{~m} / \mathrm{z}$ ve tarama hızı $1000 \mathrm{kütle} / \mathrm{s}$ ' dir. Çizelge 1 'de çilek aromasinın ve aroma mikrokapsüllerinin değerlendirilmesinde kullanılan bileşenler ve bileşenlerin literatürde yapılan tanımlamaları verilmiştir (Jetti vd., 2007; Galmarini vd., 2011; Schieberle vd., 2015; BalciTorun ve Özdemir, 2021). Sıvı çilek aromasında ve aroma kapsüllerinde depolama süresindeki değişiminin incelenmesinde bu başlıca bileşenler göz önünde bulundurulmuştur. 
Çizelge 1. Çilek aromasında tanımlanan bileşenler (Jetti vd. 2007; Galmarini vd. 2011; Schieberle vd. 2015; Balci-Torun ve Özdemir 2021)

Table1. Flavor components described in strawberry (Jetti et al. 2007; Galmarini et al. 2011; Schieberle et al. 2015;

\begin{tabular}{|c|c|}
\hline Bileşen & Aroma tanımlamas \\
\hline Compound & Definiation \\
\hline 1-Hexanol & Meyvemsi, tatlı, yeşilimsi koku \\
\hline 2-Hexanol & Meyvemsi, tatli, muz, \\
\hline 2-Hexen-1-ol, acetate & Meyvemsi, elma, armut, ekşi \\
\hline 3-Hexen-1-ol & Tatli yeşil, hafif meyveli \\
\hline 3-Hexen-1-ol, acetate & Meyvemsi, muz, elma, armut, tropik \\
\hline Ethyl butanoate* & Meyveli, çilek, elma kayısı, muz erik \\
\hline Ethyl 2-metylbutanoate* & $\begin{array}{l}\text { Meyveli, taze, meyve, üzüm, ananas, çilek mango } \\
\text { ve kiraz notalar1 }\end{array}$ \\
\hline Ethyl 3-metylbutanoate* & $\begin{array}{l}\text { Tatl, meyveli, keskin, ananas, çilek, elma yeşili } \\
\text { portakal }\end{array}$ \\
\hline Ethyl hexanoate* & $\begin{array}{l}\text { Tatlı, meyveli, ananas, çilek, yağlı ve yeşil muzlu } \\
\text { bir nüans }\end{array}$ \\
\hline 1-Butanol, 3-methyl-, acetate* & Tatll, çilek, muz, olgun meyve \\
\hline Ethyl pentanoate* & Meyveli, çilek, tatlı, ananas ve tropikal meyveler \\
\hline Hexyl acetate* & Meyveli, yeşil, elma, muz, tatlı \\
\hline Limonene & Turunçgil, portakal, taze, tatlı \\
\hline Isoamyl isovalerate ${ }^{*}$ & Tatll, meyveli, muz, çilek \\
\hline Hexanal Propylene Glycol Acetal & Tatll, meyveli, mumsu, yeşil, ananas \\
\hline 2-Propenoic acid, 3-phenyl-, methyl ester* & Tatlı çilek, kiraz \\
\hline Isobutyric acid & Tereyağı; çilek \\
\hline Benzyl benzoate & Balzamik, meyveli, pudralı nüanslar \\
\hline
\end{tabular}

\section{Nem ve su aktivitesi}

Püskürterek kurutma yöntemiyle elde edilen mikrokapsüllerin nem miktarı hızlı nem ölçüm cihaz1 ile (Kern, DBS- 60, Almanya) belirlenmiştir. Mikrokapsüllerin su aktivitesi (aw) değerleri ise su aktivitesi tayin cihazı (AquaLab, 4TE, ABD) ile oda sicaklığında $\left(25 \pm 1^{\circ} \mathrm{C}\right)$ ölçülmüştür.

\section{Yiğın yoğunluğu}

Toz çilek aroması mikrokapsüllerinde yığın yoğunluğu analizi Koç (2015)' e göre gerçekleştirilmiştir. Bu amaçla unda $2 \mathrm{~g}$ toz örnek $10 \mathrm{~mL}$ ' lik mezür içerisine tartıldıktan sonra 20 defa sert bir zemine vurularak aralardaki boşlukların kalmayıp sıkıştırılmasından sonraki hacim okunarak sonuçlar kütle/hacim oranından $\mathrm{kg} / \mathrm{m}^{3}$ olarak hesaplanmıştır.

\section{Parçacık boyutu dağılımı}

Toz çilek aroması mikrokapsüllerinin parçacık boyut dağılım analizi parçacık boyut ölçüm cihazının sivı modülü (Malvern, Mastersize 2000, wet dispersion unit, Birleşik Krallık) kullanılarak yapılmışır. Ölçümlerde propanol kullanılmış olup, sonuçlar $D_{[4,3]}$ [yüzey ağırlıklı ortalama $(\mathrm{YAO})], \mathrm{D}_{[3,2]}$ [hacim ağırliklı ortalama (HAO)], $\mathrm{D}_{10}, \mathrm{D}_{50}$ ve $\mathrm{D}_{90}$ değerleri üzerinden verilmiştir.

\section{Model Gıda Üretimi}

Püskürterek kurutma yöntemi ile üretilen çilek aroması mikrokapsülleri üretimlerinin ardından model gidalara işlenmiş ve ürünlerde duyusal analiz gerçekleştirilmiştir. Bu doğrultuda model gıda olarak çikolata ve kek seçilmiştir. Bu ürünlerin seçiminde 1sıl işlemin uygulandığ1 (kek) ve uygulanmadığ (çikolata) ürünlerdeki değişimin incelenmesi göz önünde bulundurulmuştur. 
Çikolata yapımında piyasadan temin edilen sütlü çikolata kuvertürleri ve şekillendirmede silikon çikolata kalıpları kullanılmışıtır. Çilek aromalı çikolata yapımında çikolata kuvertürü kontrollü olarak $40^{\circ} \mathrm{C}^{\prime}$ de benmari usulü eritilmiştir. Çilek aromasının (sıv1 aroma/kontrol) ve çilek aroması mikrokapsüllerinin eklenebilmesi ve kristalizasyon işlemi için sıcaklık kontrollü olarak $30{ }^{\circ} \mathrm{C}$ 'ye azaltılmıs ve aroma mikrokapsülleri ile siv1 aroma (kontrol) \%0.1 oraninda (aroma mikrokapsülü/çikolata) ilave edilerek mutfak tipi robot ile 15 dakika boyunca karıştırılmıs ardından hızlı bir şekilde kalıplara dökülmüştür. Kalıplara dökülüp şekillendirilen çikolatalar yaklaşık 15 saat oda sıcaklığında dinlendirildikten sonra duyusal analiz gerçekleştirilmiştir.

Aromalı kek üretiminde ise un (\%40), şeker $(\% 23)$, yağ $(\% 20)$, yumurta (\%16) ve kabartma tozu (\%1) kullanilarak bir hamur miksi hazırlanmış, hazırlanan miks 2 kısma ayrılarak birincisine $\% 1$ oranında ticari sıvı aroma, diğerine ise yine ayn 1 oranda aroma mikrokapsülleri eklenerek homojen dağılması amaciyla karıştırılmıştır. Hazırlanan hamur karışımları 180 ${ }^{\circ} \mathrm{C}$ ' de 30 dakika süreyle firında (Siemens, HB114FBV0T) pişirilerek, soğutulduktan sonra duyusal analizleri gerçekleştirilmiştir.

\section{Duyusal Analiz}

Duyusal analizler Akdeniz Üniversitesi, Mühendislik Fakültesi, G1da Mühendisliği Bölümü'nde görev yapan yaşları 23-35 arasında değissen 15 panelist (9 Kadın, 6 Erkek) ile yapılmıştır. Panelistlerden örnekleri görünüm, tekstür, koku, tat, hissedilen aromanın şiddeti ve genel beğeni açısından 1-5 arasında puanlandırmaları istenmiş, panel öncesi gıdaların değerlendirilmesinde aranan özellikler hakkında kısa bir bilgilendirme yapılmıştır.

\section{İstatistiksel analiz}

Çilek aromasından püskürterek kurutma yöntemi ile enkapsülasyon işlemi iki tekerrürlü, analizler ise üç paralelli olarak gerçekleştirilmiştir. Analiz sonucunda elde edilen verilere varyans analizi uygulanmış ve önemli bulunan farklllıklara ise Duncan Çoklu Karşılaştırma Testi uygulanmıştır (Düzgüneş vd., 1987). Tüm istatistiki hesaplamalar SAS programı (SAS, Cary, NC, USA) ile gerçekleştirilmiş olup değerler ortalama \pm standart hata şeklinde verilmiştir.

\section{BULGULAR VE TARTIŞMA}

Depolama süresine bağlı olarak aroma profilinin değişimi

Enkapsülasyon işlemi uygulanmamış sıvı çilek aromasinın (kontrol) depolama sicakliğ1 ve süresine bağlı olarak aroma aktif bileşenlerinin değişimi incelendiğinde (Çizelge 2), depolamanın başlangıcında çilek aromasında oldukça baskın olan "butanoic asit, 2-metil-, etil ester", "3-hexen1-ol", "3-hexen-1-ol, asetat", "hexyl asetat" ve "2propenoic asit, 3-phenyl-, metil ester" bileşenlerinin alan değerlerinin her 2 sıcaklık için de depolama süresinin artmasına bağlı olarak özellikle 30. günden itibaren başlangiç miktarlarına göre önemli oranda (> \% 90) azaldığı, yukarıdaki bileşenlerin hemen hemen tamamimin 60. gün sonunda tespit edilemediği görülmüştür. Depolamanın ilk gününde çileğe özgü bașlıca 17 aroma bileșeninin toplam alanı 58182×103 iken, depolama süresi sonunda bu alanın $4{ }^{\circ} \mathrm{C}$ ' de depolanan çilek aromalarında $204 \times 10^{3}$ e; $25^{\circ} \mathrm{C}^{\prime}$ de depolananlarda ise $166 \times 10^{3}$ ' e azaldığ 1 belirlenmiştir. Bu durum ticari olarak sıv1 formda depolanan çilek aromalarının 60 gün sonunda istenen özelliklerini neredeyse kaybettiği şeklinde yorumlanmıştır. Depolama sıcaklığı açısından çilek aroması bileşenlerinin toplam alanının değişimi irdelendiğinde ise; $4{ }^{\circ} \mathrm{C}$ ' de depolanan çilek aromalarının toplam alanının 30 gün sonunda $\% 93$ oranında, $25{ }^{\circ} \mathrm{C}^{\prime}$ de depolanan aromaların ise $\% 96$ oranında azaldığı görülmüştür.

Sıv1 formdaki aroma bileşenleri ile püskürterek kurutma yöntemiyle elde edilen aroma mikrokapsüllerinin bileşimi (Çizelge 3) karşılaştırıldığında, sıvı formda tespit edilen 2Hexen-1-ol,(E) ve 3-Hexen-1-ol bileşenlerinin toz mikrokapsüllerde belirlenemediği, enkapsülasyon sonunda ise ticari siv1 kontrol formunda bulunmayan 1-Butanol, 3-metil-,asetat bileşenlerinin mikrokapsüllerde bulunduğu görülmüştür. 
Çiželge 2. Siv formdaki çilek aromasmm bileşiminin depolama sıcakliğg ve süresine (gün) bağh olarak değģşimi (alan $x$ 103)

Table 2. Change of the composition of strawberry aroma in liquid form depending on storage temperature and time (day) $\left(\right.$ area $\left.\times 10^{3}\right)$
$4{ }^{\circ} \mathrm{C}$

\begin{tabular}{|c|c|c|c|c|c|c|c|c|}
\hline \multirow{2}{*}{$\begin{array}{l}\text { Bileşen } \\
\text { Compound }\end{array}$} & \multicolumn{4}{|c|}{$4^{\circ} \mathrm{C}$} & \multicolumn{4}{|c|}{$25^{\circ} \mathrm{C}$} \\
\hline & 0. & 15. & 30. & 60. & 0. & 15. & 30. & 60. \\
\hline $\begin{array}{l}\text { Butanoic } \\
\text { asit, 2-metil-. } \\
\text { metil ester }\end{array}$ & $1142.68^{a}$ & $1125.36^{a}$ & $50.945^{b}$ & $20.78^{b}$ & $1142.68^{a}$ & $1037.85^{a}$ & t.e. & $21.28^{b}$ \\
\hline $\begin{array}{l}\text { Butanoic } \\
\text { asit., etil ester }\end{array}$ & $7023.70^{a}$ & $405.10^{\mathrm{b}}$ & $259.45^{\mathrm{d}}$ & t.e. & $7023.70^{\mathrm{a}}$ & $341.24^{c}$ & $122.22^{\mathrm{d}}$ & t.e. \\
\hline $\begin{array}{l}\text { Butanoic } \\
\text { asit, 2-metil-. } \\
\text { etil ester }\end{array}$ & $6403.37^{a}$ & $366.46^{\mathrm{b}}$ & $245.96^{c}$ & $59.161^{d}$ & $6403.37^{a}$ & $315.28^{\mathrm{b}, \mathrm{c}}$ & $135.45^{\mathrm{d}}$ & $62.65^{\mathrm{d}}$ \\
\hline $\begin{array}{l}\text { Butanoic } \\
\text { asit, 3-metil-. } \\
\text { etil ester }\end{array}$ & $996.37 \mathrm{a}$ & $31.67^{b}$ & $46.45^{b}$ & t.e. & $996.37 \mathrm{a}$ & $38.65^{b}$ & t.e. & t.e. \\
\hline $\begin{array}{l}\text { 3-Hexen-1- } \\
\text { ol }\end{array}$ & $3101.02^{a}$ & $1580.88^{\mathrm{a}, \mathrm{b}}$ & $1024.60 \mathrm{a,b}$ & t.e. & $3101.02^{\mathrm{a}}$ & $157.10^{\mathrm{b}}$ & t.e. & t.e. \\
\hline $\begin{array}{l}\text { 2-Hexen-1- } \\
\text { ol, (E)- }\end{array}$ & $1038.89 a$ & $975.41^{b}$ & t.e. & t.e. & $1038.89^{a}$ & $929.51^{b}$ & $19.23^{b}$ & t.e. \\
\hline 1-Hexanol & $640.44^{\mathrm{a}}$ & $615.35^{\mathrm{a}}$ & $14.40^{\mathrm{b}}$ & t.e. & $640.44^{\mathrm{a}}$ & $602.85^{a}$ & t.e. & t.e. \\
\hline $\begin{array}{l}\text { Etil } \\
\text { pentanoate }\end{array}$ & $274.18^{a}$ & $250.98^{a}$ & t.e. & t.e. & $274.18^{a}$ & $236.78^{a}$ & t.e. & t.e. \\
\hline $\begin{array}{l}\text { Etil } \\
\text { hexanoate }\end{array}$ & $9469.93^{a}$ & $448.93^{b}$ & $512.16^{c}$ & 71.88 & $9469.93^{\mathrm{a}}$ & $8379.10^{\mathrm{b}}$ & $374.61^{c}$ & $63.66^{c}$ \\
\hline $\begin{array}{l}\text { 3-Hexen-1- } \\
\text { ol, asetat }\end{array}$ & $15514.04^{\mathrm{a}}$ & $15075.81^{b}$ & $1006.45^{\mathrm{d}}$ & t.e. & $15514.04^{a}$ & $14907.47^{c}$ & $905.674^{d}$ & t.e. \\
\hline Hexyl asetat & $1143.72^{a}$ & $1065.67^{a}$ & t.e. & t.e. & $1143.72^{\mathrm{a}}$ & $967.32^{\mathrm{a}}$ & t.e. & t.e. \\
\hline $\begin{array}{l}\text { 2-Hexen-1- } \\
\text { ol, asetat }\end{array}$ & $430.51^{a}$ & $427.81^{a}$ & $51.23^{\mathrm{b}}$ & $18.16^{\mathrm{b}}$ & $430.51^{a}$ & $407.60^{a}$ & $43.57^{b}$ & $19.04^{b}$ \\
\hline $\begin{array}{l}\text { Isoamyl } \\
\text { isovalerate }\end{array}$ & $7596.48^{a}$ & $368.73^{b}$ & $397.67 \mathrm{~b}$ & $34.9^{\mathrm{b}}$ & $7596.48^{a}$ & $374.74^{b}$ & $363.34^{b}$ & t.e. \\
\hline $\begin{array}{l}\text { Butanoic } \\
\text { asit, 2-metil-, } \\
\text { hexyl ester }\end{array}$ & $14.66^{\mathrm{a}}$ & $12.56^{\mathrm{a}}$ & t.e. & t.e. & $14.66^{\mathrm{a}}$ & $10.79^{a}$ & t.e. & t.e. \\
\hline $\begin{array}{l}\text { Metil } \\
\text { cinnamylate } \\
\text { 2-Propenoic }\end{array}$ & $206.58^{a}$ & $196.27^{a}$ & $192.80^{a}$ & t.e. & $206.58^{a}$ & $172.24^{\mathrm{a}}$ & $170.69^{a}$ & t.e. \\
\hline $\begin{array}{l}\text { asit, 3- } \\
\text { phenyl-, } \\
\text { metil ester }\end{array}$ & $4121.08^{a}$ & $3867.44^{a}$ & t.e. & t.e. & $4121.09^{a}$ & $3598.56^{a}$ & t.e. & t.e. \\
\hline TOPLAM & $58182.67^{a}$ & $34489.29 \mathrm{~b}$ & $4068.29 \mathrm{c}$ & $204.95^{\mathrm{d}}$ & $58182.68^{a}$ & $32477.10^{\mathrm{b}}$ & $2193.78^{\mathrm{c}, \mathrm{d}}$ & $166.56^{\mathrm{d}}$ \\
\hline
\end{tabular}

t.e.: tespit edilemedi. Aynı satırdaki farkl harfler istatistiksel fark1 ifade etmektedir $(P<0.01)$.

t.e.: not detected. Different letters in same line mean the statistical significance $(P<0.01)$. 
Çizelge 3. Püskürterek kurutma yöntemi ile elde edilen çilek aroması mikrokapsüllerinin aroma bileşiminin depolama sıcaklı̆̆1 ve süresine (gün) bağlı olarak değişimi (alan x 103)

Table 3. Change of the aroma composition of strawberry aroma microcapsules obtained by spray drying method depending on storage temperature and time (day) (area $\times 10^{3}$ )

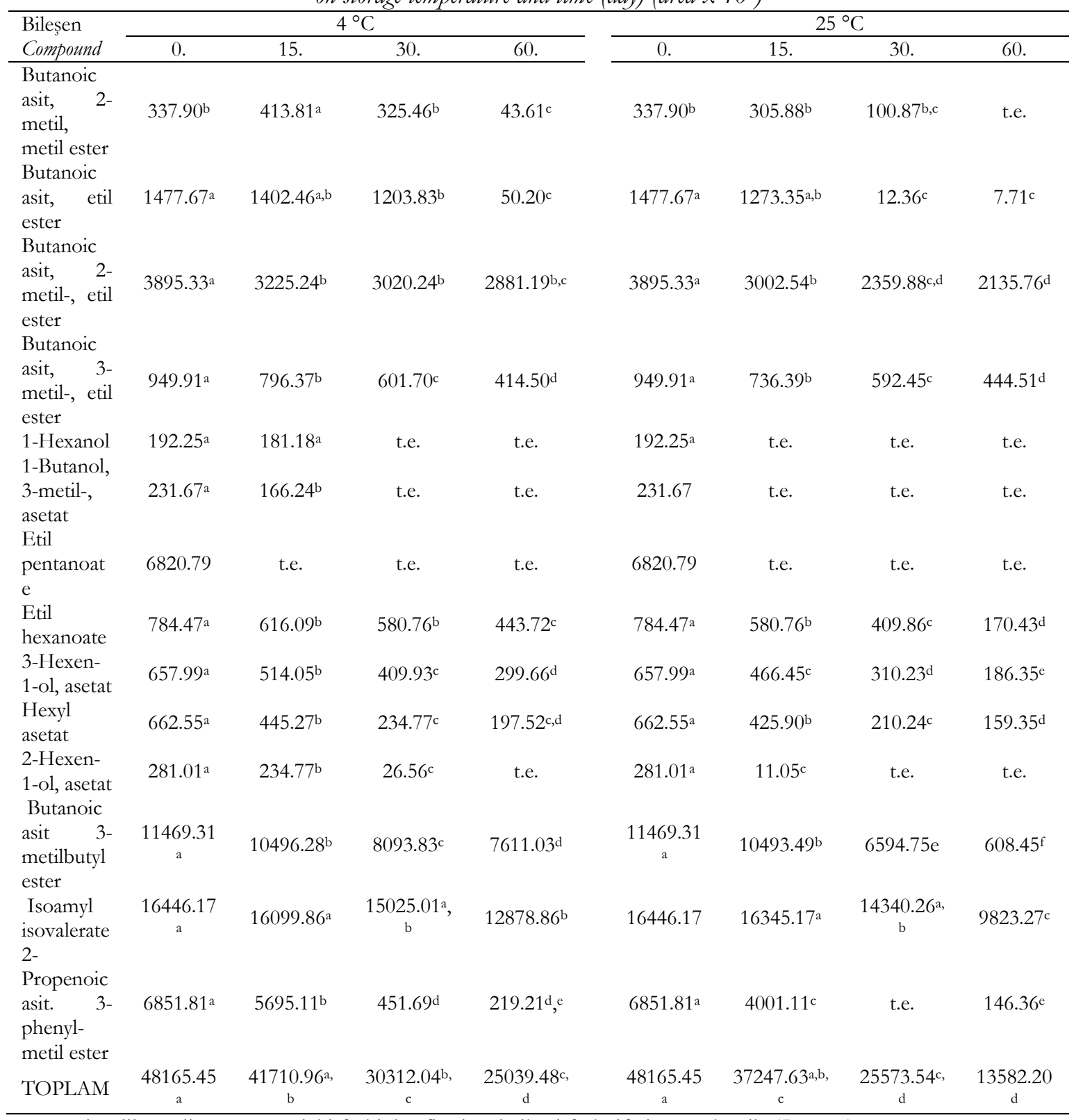

t.e.: tespit edilemedi. Aynı satırdaki farklı harfler istatistiksel farkı ifade etmektedir $(P<0.01)$.

t.e.: not detected. Different letters in same line mean the statistical significance $(P<0.01)$

Çizelge 3 incelendiğinde çilek aromasında etkili rol oynayan aroma aktif bileşenlerinin toplam alanının depolamanın başlangıcında $48165.45 \times 10^{3}$ olduğu, depolamanın sonunda $4^{\circ} \mathrm{C}^{\prime}$ de depolanan örneklerde bu alanın $25039.48 \times 10^{3}$ e; $25^{\circ} \mathrm{C}^{\prime}$ de depolanan örneklerde ise $13582.20 \times 10^{3}$ e düştügü belirlenmiştir. Çilek aromasında yüksek oranda bulunan esterlerin depolama süresince alanları incelendiğinde ise 30. güne kadar alanın çok değişmediği ancak 60. günde istatistiksel 
olarak önemli seviyede $(P<0.01)$ azalış gösterdiği görülmektedir. Benzer şekilde çilek aromasında yüksek alana sahip ve ayrica çilek aromasina meyveli, çileğimsi aromada katkı sağlayan isoamyl isovalerate bileşeninin de 30. güne kadar istatistiksel açıdan önemli seviyede $(P>0.05)$ değişmediği, 60. gün sonunda $\% 21$ oranında azaldığ1 belirlenmiştir. Bu azalış ticari formda depolanan çilek aromasinda ise depolama sonunda \%94 olarak hesaplanmıştır. Bu sonuç püskürterek kurutma yöntemiyle elde edilen çilek mikrokapsüllerinin aroma aktif bileşeni açısından depolama stabilitesinin ticari formuna göre daha yüksek olduğunu göstermektedir. Aroma mikrokapsüllerinin farklı sıcaklıklardaki aroma bileşenleri açısından depolama stabilitesi incelendiğinde ise depolama sicaklığının aroma maddelerinin korunumu açısından oldukça önemli olduğu; toplam alanın $4{ }^{\circ} \mathrm{C}^{\prime}$ de depolanan örneklerde 60 gün sonunda $\% 48$ oranında azaldığ1, $25{ }^{\circ} \mathrm{C}$ ' de depolanan örneklerde ise bu oranın $\% 72$ olduğu belirlenmiştir. Püskürterek kurutma yöntemiyle elde edilen çilek aroması mikrokapsüllerinde belirlenen aroma bileşenlerinin depolama süresine bağlı olarak salınımlarının birbirlerinden farklı oldukları görülmüş olup bu durum bileşenlerin molekül ağırlıklarının farklı olması ile ilişkilendirilmektedir (Jafari vd., 2008). Voiley vd. (1995) tarafindan arabik gam kullanilarak etil hexonate ve etil butyrate bileşenlerinin püskürterek kurutma yöntemiyle enkapsüle edildiği çalışma sonucunda molekül ağırlığı daha yüksek olan etil hexonate' in etil butyrate' a göre depolama süresine bağlı olarak daha iyi korunduğu belirlenmiştir. Araştırıcılar bu farklıllı̆ı molekül ağırlı̆̆ının artması ile difüzyonun yavaşlaması ile açıklamışlardır. Çalışma kapsamında da çilek mikrokapsüllerinde bulunan etil hexonate' in alanı depolama başlangıcında $784.47 \times 10^{3}$ olarak belirlenirken, depolama sonunda bu alan $443.72 \times 10^{3}$ olarak tespit edilmiştir. Mikrokapsüllerde belirlenen butanoic asit, etil ester bileşenin alanı ise $1477.67 \times 10^{3}$ den $50.22 \times 10^{3}$ e azalmıstır. Pellicer vd. (2019) tarafindan yapılan bir çalışmada çilek aroması farklı taşıyıcı materyaller ile (MD, HiCap, $\beta-S D$, AG) $180{ }^{\circ} \mathrm{C}$ hava giriş sıcaklığında püskürterek kurutma yöntemi ile enkapsüle edilmiş olup, MDHiCap- $\beta$-SD karışımından oluşan taşıyıcı materyal ile kurutulan örneklerin aroma maddelerini daha iyi koruduğu, kurutma sonrasi etil acetoasetat oraninin \%20.7' den \%13.4' e, benzyl alcohol bileşeninin $\% 73$ ' ten $\% 47.8$ ' e ve etil 2- asetat bileşeninin $\% 84.5^{\prime}$ ten $\% 28.1^{\prime}$ e düştüğü bildirilmiştir.

\section{Mikrokapsüllerin depolama şartlarına bağlı olarak nem ve su aktivitesi değişimi}

Toz ürünlerin nem içeriği ve su aktivitesi değerleri depolama stabilitesi açısından önem taşımakta olup, 0.65 altındaki su aktivitesi değerleri mikrobiyal açıdan güvenilir olsa da, kimyasal ve biyokimyasal reaksiyonlar açısından 0.2-0.3 arasındaki su aktivitesi değerlerinin güvenilir aralık olduğu belirtilmektedir (Acar ve Cemeroğlu, 1999). Depolama başlangicinda \%3.36 olan toz mikrokapsüllerin nem miktarı değerleri, 60 günlük depolama süresi sonunda $4{ }^{\circ} \mathrm{C}^{\prime}$ de depolanan örnekler için $\% 4.43 ; 25^{\circ} \mathrm{C}^{\prime}$ de depolanan örnekler için ise \%4.39 olarak belirlenmiştir (Çizelge 4). Benzer şekilde örneklerin su aktivitesi değerleri de depolama süresine bağlı olarak istatistiksel açıdan önemli derecede $(P<0.01)$ artış göstermiştir. Depolama süresi sonunda toz mikrokapsüllerin su aktivitesi değerleri 4 ve $25{ }^{\circ} \mathrm{C}^{\prime}$ de depolanan örnekler için sirasiyla 0.37 ve 0.39 olarak belirlenmiş olup (depolama başlangıcında bu değerler sirasiyla 0.14 ve $0.18^{\prime}$ dir), bu değerlerin kimyasal-biyokimyasal açıdan güvenli aralığın dışında olduğunu söylenebilir.

\section{Mikrokapsüllerin depolamaya bağlı olarak yığın yoğunluğu değişimi}

Yığın yoğunluğu toz ürünler için önemli parametrelerden biri olup, gidaların akış özelliklerini, depolama stabilitesini ve ambalaj hacmini etkilemektedir. Sonuçlar incelendiğinde her iki depolama sıcaklığı için de depolama süresine bağlı olarak örneklerin yığın yoğunluğu değerlerinin istatistiki açıdan önemli derecede $(P>0.05)$ olmasa da azaldığı görülmektedir (Çizelge 4). $\mathrm{Bu}$ azalışın ürünlerin nem miktarındaki artış ile ilişkilendirilmesi mümkündür. Literatürde toz ürünlerin depolama süresi ile birlikte kitle yoğunluklarının arttığının bildirildiği bazı çalışmalar (Samborska vd., 2015; Muzaffar ve Kumar, 2016) olsa da; Chang vd. (1998) toz gidaların su aktivitesi değerinin 
artmasiyla kitle yoğunluğu değerlerinin arttığ belirtilmiş ve bu artışı sıvı köprüler ile toz partiküllerin arasındaki boşlukların azalmasıyla ilişkili olduğu rapor edilmiştir.

\section{Mikrokapsüllerin depolamaya bağlı olarak parçacık boyutu dağılımının değişimi}

Toz mikrokapsüllerin boyutlarının değişimi gıdaların dokusunu ve duyusal özelliklerini etkilediğinden dolayı gida endüstrisinde ürünlere işlenen kapsüllenmiş bileşenlerin gıdanın dokusunu, duyusal özelliklerini, rengini veya tadını etkilememesi arzu edilmektedir. Çalışma kapsamında püskürterek kurutma yöntemi ile toz forma dönüştürülen ve farklı sıcaklıklarda depolanan aroma kapsüllerinin parçacık boyutu dağılımı depolama süresince ölçülerek depolama şartlarının kapsüllerin boyutu üzerindeki etkisi belirlenmiş̧tir. Toz ürünlerin $\mathrm{D}_{[4.3]}$ hacim ağırlıklı ortalama $(\mathrm{HAO})], \mathrm{D}_{[3.2]}$ [yüzey ağırliklı ortalama (YAO)], $\mathrm{D}_{10}, \mathrm{D}_{50}$ ve $\mathrm{D}_{90}$ değerleri Çizelge 5'te, parçacık boyutu dağılımları ise Şekil 1' de verilmiştir. Sonuçlarda ifade edilen $\mathrm{D}_{[4.3]}$ değeri genellikle parçacık sayısının önemsiz olduğu durumlarda kullanılmakta iken, aktif yüzeylere sahip parçacıklarda veya yüzey alanının önemli olduğu durumlarda $\mathrm{D}_{[3.2]}$ değeri kullanılmaktadır. Ayrıca parçacık büyüklügünü ifade etmek için kullanılan $\mathrm{D}_{10}, \mathrm{D}_{50}$ ve $\mathrm{D}_{90}$ değerleri sirasıyla mikrokapsül çaplarının \%10' unun, \%50' sinin ve $\% 90$ ' inın belirtilen değere eşit ya da bu değerlerin altında bir değer olduğunu belirtmektedir.

Çizelge 4. Püskürterek kurutma yöntemi ile elde edilmiş çilek mikrokapsüllerinin depolamaya bağlı nem ve su aktivitesi değişimi

Table 4. Change of moisture content, water activity, and bulk density of strawberry microcapsules obtained by spraydrying method

\begin{tabular}{lcccc}
\hline $\begin{array}{l}\text { Sicaklik } \\
\text { Temperature }\end{array}$ & $\begin{array}{c}\text { Süre (gün) } \\
\text { Time (day) }\end{array}$ & $\begin{array}{c}\text { Nem miktarl }(\%) \\
\text { Moisture content (\%) }\end{array}$ & $\begin{array}{c}\text { Su } \\
\text { aktivitesi } \\
\text { Water } \\
\text { activity }\end{array}$ & $\begin{array}{c}\text { Yiğın yoğunluğu }\left(\mathrm{kg} / \mathrm{m}^{3}\right) \\
\text { Bulk, density }\left(\mathrm{kg} / \mathrm{m}^{3}\right)\end{array}$ \\
\hline & 0. & $3.36^{\mathrm{c} \pm 0.21}$ & $0.14^{\mathrm{c} \pm 0.01}$ & $351.60 \pm 1.76$ \\
$4^{\circ} \mathrm{C}$ & 15. & $4.02^{\mathrm{b}} \pm 0.06$ & $0.22^{\mathrm{b}} \pm 0.06$ & $350.44 \pm 5.60$ \\
& 30. & $4.21^{\mathrm{ab} \pm 0.26}$ & $0.29^{\mathrm{ab}} \pm 0.07$ & $348.77 \pm 1.39$ \\
& 60. & $4.43^{\mathrm{a}} \pm 0.28$ & $0.37^{\mathrm{a}} \pm 0.03$ & $347.59 \pm 2.93$ \\
\hline $25^{\circ} \mathrm{C}$ & 0. & $3.36^{\mathrm{b}} \pm 0.21$ & $0.18^{\mathrm{b}} \pm 0.01$ & $351.60 \pm 1.76$ \\
& 15. & $3.78^{\mathrm{b}} \pm 0.18$ & $0.27 \mathrm{ab} \pm 0.03$ & $350.83 \pm 11.27$ \\
& 30. & $4.07^{\mathrm{ab}} \pm 0.05$ & $0.34^{\mathrm{a}} \pm 0.00$ & $348.82 \pm 0.38$ \\
\hline
\end{tabular}

Aynı sütundaki farklı harfler istatistiksel farkı ifade etmektedir $(P<0.01)$

Different letters in same column mean the statistical significance $(P<0.01)$.

Çizelge 5. Çilek mikrokapsüllerinin depolamaya bağlı parçaçık boyutu değişimi ( $\mu \mathrm{m})$ Table 5. Change of particle size of strawberry microcapsules during storage (um)

\begin{tabular}{ccccccc}
\hline & & $\mathrm{D}_{10}$ & $\mathrm{D}_{50}$ & $\mathrm{D}_{90}$ & $\mathrm{D}_{[3.2]}$ & $\mathrm{D}_{[4.3]}$ \\
\hline \multirow{4}{*}{$4^{\circ} \mathrm{C}$} & 0. & $1.17^{\mathrm{a}} \pm 0.01$ & $10.14^{\mathrm{b}} \pm 0.47$ & $22.91^{\mathrm{c}} \pm 0.06$ & $3.61^{\mathrm{c}} \pm 0.01$ & $12.86^{\mathrm{b}} \pm 0.10$ \\
& 15 & $1.32^{\mathrm{a}} \pm 0.21$ & $10.35^{\mathrm{b}} \pm 0.01$ & $25.82^{\mathrm{b}} \pm 0.19$ & $4.60^{\mathrm{a}} \pm 0.02$ & $11.83^{\mathrm{b}} \pm 0.01$ \\
& 30. & $1.89^{\mathrm{b}} \pm 0.01$ & $10.42^{\mathrm{b}} \pm 0.14$ & $26.07^{\mathrm{b}} \pm 0.14$ & $4.60^{\mathrm{a}} \pm 0.01$ & $12.76^{\mathrm{b}} \pm 0.03$ \\
& 60. & $1.99^{\mathrm{b}} \pm 0.17$ & $11.77^{\mathrm{a}} \pm 0.07$ & $28.28^{\mathrm{a}} \pm 0.65$ & $4.12^{\mathrm{b}} \pm 0.26$ & $15.02^{\mathrm{a}} \pm 0.88$ \\
\hline \multirow{3}{*}{$5^{\circ} \mathrm{C}$} & 0. & $1.17^{\mathrm{b}} \pm 0.01$ & $10.14^{\mathrm{c}} \pm 0.47$ & $22.91^{\mathrm{c}} \pm 0.06$ & $3.61^{\mathrm{c}} \pm 0.01$ & $12.86^{\mathrm{b}} \pm 0.10$ \\
& 15. & $2.16^{\mathrm{a}} \pm 0.11$ & $11.16^{\mathrm{b}} \pm 0.03$ & $27.29^{\mathrm{b}} \pm 0.58$ & $3.83^{\mathrm{c}} \pm 0.04$ & $14.84^{\mathrm{a}} \pm 0.16$ \\
& 30. & $2.14^{\mathrm{a}} \pm 0.04$ & $12.30^{\mathrm{b}} \pm 0.04$ & $27.42^{\mathrm{b}} \pm 0.23$ & $4.79^{\mathrm{b}} \pm 0.05$ & $14.03^{\mathrm{b}} \pm 0.22$ \\
& 60. & $2.35^{\mathrm{a}} \pm 0.17$ & $12.93^{\mathrm{a}} \pm 0.02$ & $27.87^{\mathrm{a}} \pm 0.56$ & $5.11^{\mathrm{a}} \pm 0.03$ & $14.57^{\mathrm{a}} \pm 0.24$ \\
\hline
\end{tabular}

Aynı sütundaki farklı harfler istatistiksel fark1 ifade etmektedir $(P<0.01)$

.Different letters in same column mean the statistical significance $(P<0.01)$. 


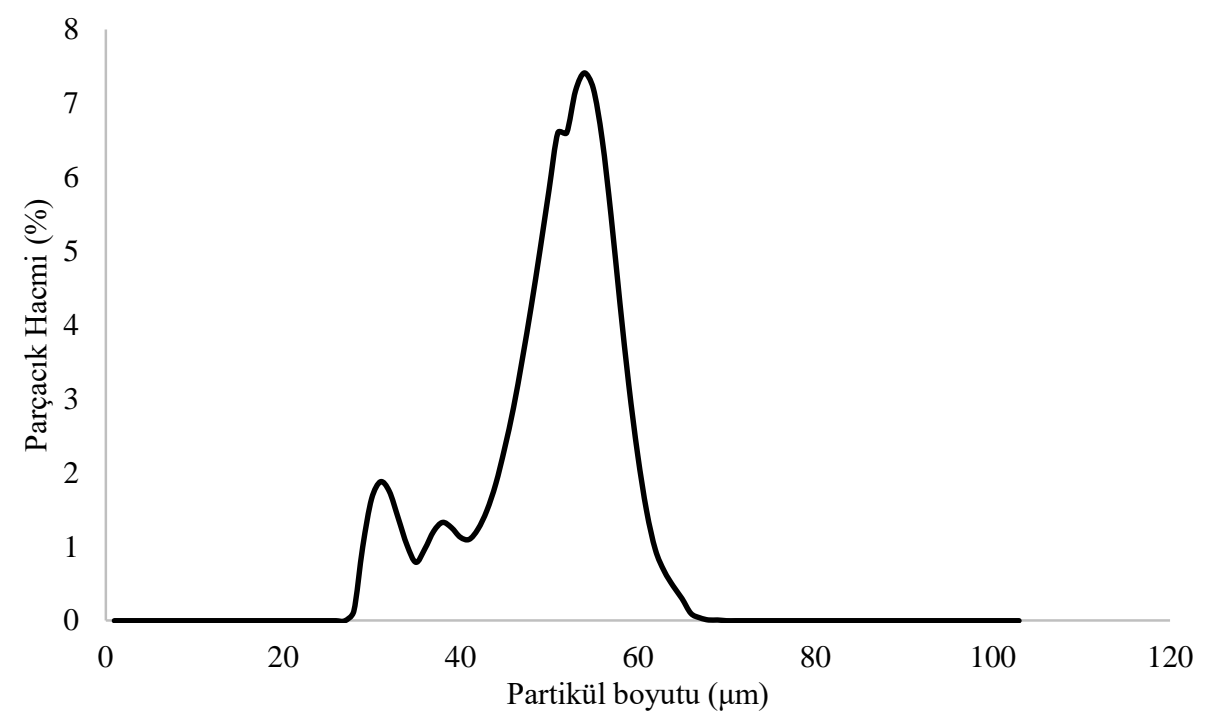

Şekil 1. Püskürterek kurutma yöntemi ile elde edilen çilek aroması kapsüllerinin parçacık boyutu dağılımı

Figure 1. Particle size distribution of strawberry aroma microcapsules obtained by spray drying method

Toz mikrokapsüllerin depolama sicaklı̆g ve süresine bağl1 olarak $\mathrm{D}_{10}$ değerlerinin 1.17-2.35 $\mu \mathrm{m}, \quad \mathrm{D}_{50}$ değerlerinin 10.14-12.93 $\mu \mathrm{m}, \quad \mathrm{D}_{90}$ değerlerinin 22.91-28.28 $\mu \mathrm{m}, \mathrm{D}_{[3.2]}$ değerlerinin 3.61-5.11 $\mu \mathrm{m}$ ve $\mathrm{D}_{[4.3]}$ değerlerinin ise 11.83-15.02 $\mu \mathrm{m}$ arasında değisstiği belirlenmiştir. Sonuçlar incelendiğinde çilek aroması mikrokapsüllerinin başlangıç $\mathrm{D}_{50}$ değerinin $10.14 \mu \mathrm{m}$ olduğu ve depolama süresi sonunda bu değerinin $4{ }^{\circ} \mathrm{C}$ ' de depolanan örneklerde $11.77 \mu \mathrm{m}$ ' ye ve $25{ }^{\circ} \mathrm{C}$ 'de depolanan örneklerde ise $12.93 \mu \mathrm{m}$ ', ye yükseldiği görülmektedir. Depolama süresi ve sıcaklı̆̆ının artması ile çilek aroması mikrokapsüllerinin parçacık boyutundaki artış nem absorbsiyonuna bağlı gerçekleşen ve topaklanma olarak bilinen, partiküllerin birbirine yapışması ile ilişkilendirilmiştir. Partikül boyutunun depolama koşullarından etkilenebileceği, artan sıcaklıkla birlikte, depolanan materyalin özelliğine bağl1 olarak partikül boyutunun azalabileceği ya da artabileceği rapor edilmiştir (Koç vd., 2015). Çalışma sonuçlarına paralel olarak limonen aromasının arabik gam kullanılarak püskürterek kurutma yöntemi ile mikrokapsülasyonunun araştırıldığı bir çalışmada örneklerin $\mathrm{D}_{50}$ değerinin depolama süresi sonunda $15.7 \mu \mathrm{m}$ ' den $23.2 \mu \mathrm{m}$ ' e yükseldiği bildirilmiştir (Bertolini vd., 2001).

\section{Duyusal analiz sonuçları}

Aroma maddeleri g1da endüstrisinde pastacıllk ürünleri, içecekler, süt ürünleri, atıştırmalık çerezler, çikolatalar, şekerlemeler ve sakızlar gibi birçok üründe kullanılmaktadır. Çalışma kapsamında toz forma getirilmiş çilek aromasının beğeni durumunun ortaya koyulabilmesi amaciyla mikrokapsüller hazırlanan çikolataya ve keke ilave edilmiştir. Sonuçlar incelendiğinde kapsüllenen çilek aroması ile üretilen çikolatalarda test edilen duyusal özelliklerin panelistler tarafindan daha çok beğenildiği (Şekil 2), özellikle de aroma şiddeti, koku, tat ve genel beğeni açısından kapsüllenmiş örneklerin istatistiksel olarak da önemli derecede $(P<0.01)$ daha yüksek puan aldığ1 görülmektedir (Çizelge 6 ).

Çilek aroması kullanılarak üretilen keklerin duyusal analiz verilerine bakıldığında da benzer şekilde koku, aroma şiddeti ve genel beğeni sonuçlarında püskürterek kurutma yöntemi ile kapsüllenmiş çilek aroması kullanılarak üretilen keklerin, ticari sıv1 formda üretilen keklere göre daha yüksek puan aldığ1 $(P<0.01)$ görülmektedir. $\mathrm{Bu}$ sonuçlar enkapsülasyon işlemi ile üretim sırasındaki koşullara karşı daha stabil çilek aromasının elde edilebildiğini göstermiştir. 
Çizelge 6. Çilek aromalı çikolata ve keklere ait duyusal analiz sonuçları

Table 6. Sensory analysis results of chocolate and cakes flavored by strawberry aroma

\begin{tabular}{|c|c|c|c|c|c|c|}
\hline Çikolata & Görünüm & Tekstür & Koku & Tat & Aroma şiddeti & Genel beğen \\
\hline Chocolate & Appearance & Texture & Odor & Taste & Aroma intensity & General taste \\
\hline $\begin{array}{l}\text { Ticari-Siv1 } \\
\text { Commercial-Liquid }\end{array}$ & $4.88 \pm 0.12$ & $4.75 \pm 0.25$ & $3.88^{b} \pm 0.29$ & $4.63 \pm 0.18$ & $2.75^{b} \pm 0.31$ & $4.25^{\mathrm{b}} \pm 0.25$ \\
\hline $\begin{array}{l}\text { Toz-Kapsül } \\
\text { Powder-Capsule }\end{array}$ & $5.00 \pm 0.00$ & $4.63 \pm 0.26$ & $4.75^{\mathrm{a}} \pm 0.16$ & $4.88^{a} \pm 0.12$ & $4.38 \mathrm{a} \pm 0.26$ & $4.75^{\mathrm{a}} \pm 0.16$ \\
\hline $\begin{array}{l}\text { Kek } \\
\text { Cake }\end{array}$ & & & & & & \\
\hline $\begin{array}{l}\text { Ticari-Siv1 } \\
\text { Commercial-Liquid }\end{array}$ & $4.00 \pm 0.19$ & $4.25 \pm 0.25$ & $3.38^{\mathrm{b}} \pm 0.26$ & $3.50^{\mathrm{b}} \pm 0.76$ & $2.63^{b} \pm 0.32$ & $3.50^{\mathrm{b}} \pm 0.19$ \\
\hline $\begin{array}{l}\text { Toz-Kapsül } \\
\text { Powder-Capsule }\end{array}$ & $4.50 \pm 0.19$ & $4.38 \pm 0.18$ & $4.38 \mathrm{a} \pm 0.26$ & $4.88^{a} \pm 0.35$ & $4.00^{a} \pm 0.38$ & $4.63 a \pm 0.18$ \\
\hline
\end{tabular}

Aynı sütundaki farklı harfler istatistiksel fark1 ifade etmektedir $(P<0.01)$

.Different letters in same column mean the statistical significance $(P<0.01)$.

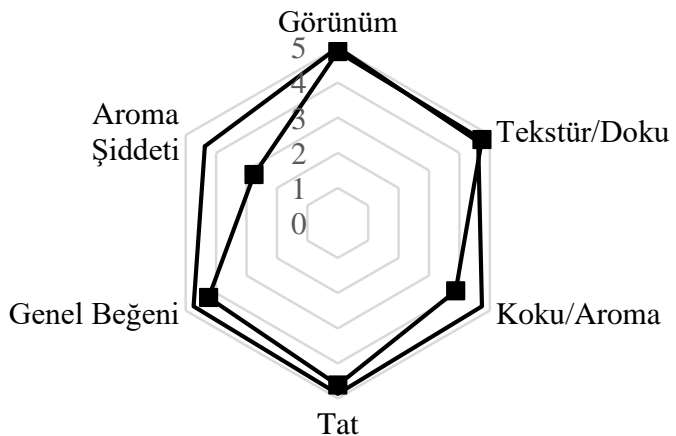

$\longrightarrow$ Toz Aroma $\rightarrow$ Siv1 Aroma

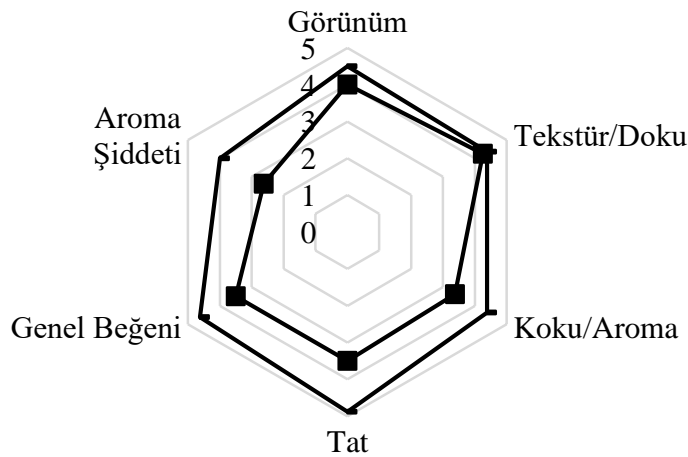

$\longrightarrow$ Toz Aroma $\rightarrow$ Siv1 Aroma

$\mathrm{b}$

Şekil 2. Çilek aromalı çikolata (a) ve keklere (b) ait duyusal analiz sonuçları

Figure 2. Sensory analysis results of chocolate (a) and cakes (b) flavored by strawberry aroma

\section{SONUÇ}

Ekonomik değeri oldukça yüksek olan aroma maddelerinin depolama stabilitelerini arttırmak ve işlenmeleri sırasındaki salınımlarının kontrolünü sağlamak oldukça önemlidir. Son yıllarda, gıda endüstrisinde oksijen, nem, sicaklık, 1şık ve benzeri çevre koşullarına karşı koruma sağlayan ve aktif bileşenin doğru yerde, doğru zamanda kontrollü salınımına olanak veren enkapsülasyon uygulamaları gittikçe yaygınlaşmaktadır. Nitekim bu çalışma ile sıvı formdaki çilek aromasının püskürterek kurutma yöntemi ile başarllı bir şekilde enkapsüle edilebileceği ve bu yöntemle elde edilen mikrokapsüllerin depolama kararlılığının arttırabileceği görülmüştür. Çalışma sonuçları sıvı formda toplam aroma bileşenlerinde 60 günlük depolama süresi sonunda $\% 95$ 'den fazla oranda kaybın meydan geldiğini, bu kaybın enkapsülasyon işlemiyle $4{ }^{\circ} \mathrm{C}$ ' de depolanan örneklerde yarı yarıya azaltılabildiğini göstermiştir. 
Depolama sıcaklığının artması ile birlikte aroma salınımının da arttı̆̆ görülmüştür. Toz mikrokapsüllerin depolama süresince nem absorbe ettikleri, buna bağlı olarak su aktivitesi değerlerinin arttı̆̆1 ve özellikle 60 günlük depolama süresi sonunda kimyasal reaksiyonlar açısından su aktivitesi değerlerinin kritik bir noktaya geldikleri tespit edilmiştir. Nem absorbsiyonuna bağlı olarak tozların depolama süresi ile birlikte partikül boyutlarının arttığ1 ve kitle yoğunluklarının ise azaldığı görülmüştür. Bu anlamda elde edilen sonuçlar, aroma maddelerinin iyi bir şekilde ambalajlanarak depolanması gerektiğini göstermiştir. Çilek aroması mikrokapsülleri ile üretilen çikolata ve kek duyusal açıdan ticari forma göre üretilen ürünlere göre daha fazla beğenilmiş olup, özellikle aroma şiddetinin enkapsüle edilen aromalarla üretilen gıdalarda daha fazla hissedildiği görülmüștür. Bu sonuç aroma enkapsülasyonu ile gidaların işlenmesi sırasında kararlılık sağlanabileceğini de göstermiştir.

\section{ÇIKAR ÇATIŞMASI BEYANI}

Bu makalede yer alan yazarların arasında herhangi bir çıkar çatışmasının olmadığını beyan ederiz.

\section{YAZARLARIN KATKISI}

Ferhan BALCI TORUN, analizlerinin yapilması, sonuçların istatistiksel olarak değerlendirilmesi aşamalarında ve makalenin yazım sürecinde; Feramuz ÖZDEMIR, çalışma planının kurulması, çalışmanın yürütülmesi ve makalenin yazım sürecinde katkıda bulunmuştur.

\section{TEŞEKKÜR}

Bu çalışmayı maddi olarak destekleyen Akdeniz Üniversitesi Bilimsel Araştırma Projeleri Birimi'ne (FDK-2015-768) ve aromaların teminindeki desteklerinden dolayı Aromsa Besin Aroma ve Katkı Maddeleri Sanayi Ticaret A.Ş’ye teşekkür ederiz.

\section{KAYNAKLAR}

Acar, J., B. Cemeroğlu. (1999). Meyve ve sebze teknolojisi. Hacettepe Üniversitesi Mühendislik Fakültesi Yayınları Yayın: 43,399.

Anonim (2013). www.tarim.gov.tr
Balc1-Torun, F., (2019). Farklı enkapsülasyon yöntemleri kullanılarak elde edilen aroma kapsüllerinin depolama stabilitesinin ve gıda katkı maddesi olarak kullanımının araştırılması. Akdeniz üniversitesi Fen Bilimleri Enstitüsü Gıda Mühendisliği Anabilim Dalı Doktora Tezi, Antalya, Türkiye, $182 \mathrm{~s}$.

Balc1-Torun, F., Özdemir, F., (2021). Encapsulation of strawberry flavour and physicochemical characterization of the encapsulated powders. Powder Tech, 380, 602612.

Bertolini, A., Siani, A., Grosso, C. (2001). Stability of monoterpenes encapsulated in gum arabic by spray-drying. J. Agric. Food Chem., 49(2): 780-785.

Bhandar1., B.R., Howes, T. (1999). Implication of glass transition for the drying and stability of dried foods. Journal of Food Engineering, 40: 71-79.

Burdock, G. A. (1998). Review of the biological properties and toxicity of bee propolis (propolis). Food and Chemical toxicology, 36(4), 347-363.

Chang, K.S., Kim, D.W., Kim, S.S., Jung, M.Y. (1998). Bulk flow properties of model food powder at different water activity. International Journal of Food Properties, 1(1): 45-55.

Düzgüneş, O., et al. "Araştırma ve Deneme Metotlar1 (İstatistik Metotlar1-II), Ankara Üniversitesi, Ziraat Fakültesi Yayınlar1, 1021." Ders kitab1 295 (1987).

Forney, C.F., Kalt, W., Jordan M.A. (2000). The Composition of Strawberry Aroma Is Influenced by Cultivar, Maturity, and Storage. Hortscience, 35:6, 1022-1026.

Galmarini, M.V., Baren, C., Zamora, M.C., Chirife,J., Lira, P., L., Bandoni, A. (2011). Impact of trehalose, sucrose and /or maltodextrin addition on aroma retention in freeze dried strawberry puree. Int.J. Food Sci. Technol. 46, 13371345

Gibbs F., Kermasha S., Alli I., Mulligan C.N. (1999). "Encapsulation in the food industry: a review." Int J Food Sc Nutr, 50:3: 213-224.

Jafari, S.M., Assadpoor, E., He, Y., Bhandari, B. (2008). Encapsulation efficiency of food flavours 
and oils during spray drying. Drying Technol., 26(7): 816-835.

Jetti, R.R., Yang, E., Kurnianta, A., Finn, C., Qian, M.C., (2007). Quantification of selected aromaactive compounds in strawberries by headspace solid-phase microextraction gas chromatography and correlation with sensory descriptive analysis. Journal of Food Science 72.

Jimenez, M., Garcia, H.S, Berıstain, C.I. (2004). Spray-drying microencapsulation and oxidative stability of conjugated linoleic asit, European Food Research and Technology, 219: 588-592.

Karaoglu, M., Kotanc1lar, H., Çelik, İ. (1998). Modifiye nişaşta eldesi ve firın ürünlerinde kullanımı. Atatürk Üniversitesi Dergisi, 29(2): 359368.

Kargel, B. C. W. (2000). Effect of polymeric phase transitions on the controlled release and oxidative stability of flavor model systems encapsulated in traditional carbohydrate carriers. Ph.D. Thesis, Faculty of the Graduate School, University of Minnesota, USA.

Koç, M. (2015). Farklı kurutma yöntemleri ile bal tozu üretim koşullarının optimize edilmesi ve depolama stabilitesinin belirlenmesi. Doktora tezi, Ege Üniversitesi, Fen Bilimleri Enstitüsü, İzmir, $202 \mathrm{~s}$

Koç, M., Güngör, Ö., Zungur, A., Yalçın, B., Selek, İ., Ertekin, F.K., Ötles, S. (2015). Microencapsulation of extra virgin olive oil by spray drying: effect of wall materials composition, process conditions, and emulsification method. Food Bioproc Technol, 8 (2):301-318.

Koç, M., Sakin, M., Ertekin, F. (2010). Mikroenkapsülasyon ve gida teknolojisinde kullanımı. Pamuk.kale Üniversitesi Mühendislik. Bilimleri Dergisi, 16: 77-86.

Krishnan, S., Bhosale, R., Singhal, R.S. (2005). Microencapsulation of cardamom oleoresin: evaluation of blends of gum arabic, maltodextrin and a modified starch as wall materials, Carbobydrate Polymers, 61: 95-102

Madene A., Jacquot M, Scher J., Desorby S. (2006) Flavour encapsulation and controlled release-a review. International Journal of Food Science and Technology, 1, 1-21.

Mahdavi, S.A., Jafari, S.M., Assadpoor, E., Dehnad, D. (2016). Microencapsulation optimization of natural anthocyanins with maltodextrin, gum arabic and gelatin. Int. J. Biol. Macromol., 85: 379-385.

Muzaffar, K., Kumar, P. (2016). Moisture sorption isotherms and storage study of spray dried tamarind pulp powder. Powder Technol, 291: 322-327.

Pelayo, C., Ebeler, S. E., A. A. Kader. (2003) "Postharvest life and flavor quality of three strawberry cultivars kept at $5 \mathrm{C}$ in air or air+ 20 kPa CO2." Postharvest Biology and Technology 27,2: 171-183.

Pellicer, J.A., Fortea, M.I., Trabal, J., RodríguezLópez, M.I., Gabaldón, J.A., Núñez-Delicado, E. (2019). Stability of microencapsulated strawberry flavour by spray drying, freeze drying and fluid bed. Powder Technol., 347: 179-185.

Pizzoni, D., Compagnone, D., Di Natale, C., D’Alessandro, N., Pittia, P. (2015). Evaluation of aroma release of gummy candies added with strawberry flavours by gaschromatography/mass-spectrometry and gas sensors arrays. Journal of Food Engineering, 167, 7786.

Quek, S.Y., Chok, N. K., Swedlund, P. (2007). The physicochemical properties of spray-dried watermelon powders. Chemical Engineering and Processing, 46: 386-392.

Re, M.I. (1998). Microencapsulation by spray drying, Drying Technology, 16: 11951236.

Rodriguez-Huezo, M.E., Pedroza-Islas, R., Prado-Barragan, L.A., Beristain, C.I., VernonCarter, E.J. (2004). Microencapsulation by spray drying of multiple emulsions containing carotenoids, Journal of Food Science, 69: 351-359.

Samborska, K., Langa, E., Bakier, S. (2015). Changes in the physical properties of honey powder during storage. International Journal of Food Science and Technology, 50: 1359-1365. 
Schieberle, P., Hofmann, T., (1997). Evaluation of the character impact odorants in fresh strawberry juice by quantitative measurements and sensory studies on model mixtures. Journal of Agricultural and Food Chemistry, 45(1), 227-232.

Torun, M., Özdemir, F. (2011). Lezzet artırıc1 gida katk1 maddesi: Monosodyum Glutamat (MSG). Turkechem, 21: 40-42.

Voilley, A.J. (1995). Flavor encapsulation: Influence of encapsulation media on aroma retention during drying. Chapter 15, pp 169-179.

Zabetakis, I. (1997). Enhancement of flavour biosynthesis from strawberry (Fragaria $\mathrm{x}$ ananassa) callus cultures by Methylobacterium species. Plant cell, tissue and organ culture, 50(3), 179183.
Zabetakis, I., Holden, M. A. (1997). Strawberry flavour: analysis and biosynthesis. Journal of the Science of Food and Agriculture, 74(4), 421-434.

Zeller, B.L., Saleeb, F.Z., Ludescher, R.D. 1999. Trends in development of porous carbohydrate food ingredients for use in flavor encapsulation, Trends in Food Science and Technology, 9: 389-394.

Zhu, G.Y., Xiao, Z.B., Zhou, R.J., and Yi, F. P. (2012). Fragrance and flavor microencapsulation technology. In Advanced Materials Research (Vol. 535, pp. 440-445). Trans Tech Publications Ltd.

Zuidam, N. J., and Heinrich, E. (2010). Encapsulation of aroma. In Encapsulation technologies for active food ingredients and food processing (pp. 127-160). Springer, New York, NY. 